\title{
Organic Research and Development in Denmark (1996-2010) - Effects on the Organic Sector and Society
}

\author{
Lise Andreasen ${ }^{1}$, Ilse Ankjær Rasmussen ${ }^{1} \&$ Niels Halberg ${ }^{1}$ \\ ${ }^{1}$ International Centre for Research in Organic Food Systems (ICROFS), Tjele, Denmark \\ Correspondence: Lise Andreasen, International Centre for Research in Organic Food Systems (ICROFS), \\ Blichers Alle 20,8830 Tjele, Denmark. Tel: 45-8715-7771. E-mail: lise.andreasen@icrofs.org
}

Received: June 3, 2015 Accepted: July 10, 2015 Online Published: July 15, 2015

doi:10.5539/sar.v4n3p173 URL: http://dx.doi.org/10.5539/sar.v4n3p173

\begin{abstract}
The ICROFS (International Centre for Research in Organic Food Systems) has conducted an analysis of the effects of organic research in Denmark (1996-2010) on the Danish organic sector and on society in general. Over these 15 years, three national programs and one program with European collaboration have been implemented in Denmark, financed via special government grants that amounted to just over 500 million DKK (approx. $€ 67$ million - or approximately $\$ 80$ million). The analysis itself was carried out as a compilation of information from three perspectives, each of which has been independently documented:
\end{abstract}

- Interviews with (representatives of) end-users of results from research and development (R\&D) investigating their assessment of the challenges in the sector and solutions developed from 1996-2010

- Assessment of the R\&D endeavours in different thematic areas (dairy/milk, pigs, crops, etc.) as they related to end-users and the stated challenges at that time

- Documentation of the dissemination of R\&D results in relation to themes and challenges in the sector

The results showed very good correspondence between end-users' perceptions of the challenges overcome in the sector, the R\&D initiated in the research programmes, and the dissemination of research results and other forms of knowledge transfer. The analysis documented direct effects of the research initiatives targetting the challenges in the sector such as higher yields, weed and pest control, animal health and welfare, the potential for phasing out the use of antibiotics in Danish dairy herds and reducing the problems caused by seedborne diseases. It also describes where research did not contribute as much to overcoming challenges. In contrast, the analysis showed that the effects of the research in the organic processing industry and among relevant governmental and non-governmental organisations were of a more indirect character. Research has helped stabilize the supply and quality of raw materials at a time of growing demand and sales. Organic research also generates new knowledge and leads to new opportunities that can provide inspiration for a green conversion, product diversification and growth also in conventional agriculture. The analysis showed that research under the national research programs overall have been very applied and directed at the barriers in the sector in order to support the general market and growth conditions for the organic sector. Having laid a solid foundation, the private sector has been able to take advantage of commercial opportunities when demand grew, while adhering to the organic policy objectives of the market-driven growth in the organic sector.

Keywords: organic research, analysis, effect, impact analysis, food production, organic sector, organic growth, Denmark

\section{Introduction}

\subsection{The organic Sector in Denmark}

Since the mid-1980s organic farming in Denmark has been promoted through political initiatives in order to respond to consumers' demand for organic products. The policies of governments during the past decades have included financial support for the conversion of conventional farms, regulation and control, advisory services, information campaigns, and education and research in organic farming (Halberg et al., 2012). At the end of the 1980s and start of the 1990s Danish research in organic farming was primarily carried out on private farms and in long-term crop rotations at research stations around the country (Halberg et al., 2012). With the first action plan [Action Plan I (Det økologiske Fødevareråd, 1995)] for the promotion of organic food production prepared 
by the Ministry of Agriculture and Fisheries in 1995 and followed by Action Plan II (Det økologiske Fødevareråd, 1999) in 1999, research in organic farming was given a higher priority than earlier times, which resulted in the development of a national research program and the establishment of the Danish Research Centre for Organic Farming (DARCOF) [now the International Centre for Research in Organic Food Systems (ICROFS)] - a 'centre without walls' to coordinate these programs as research continued within existing research environments throughout the EU.

From 1996-2010 Denmark had four research programs in organic farming and foods financed via special government grants (one of them with European collaboration). While the first program primarily addressed issues related to the primary production (Halberg et al., 2012) the following programs also included issues related to industry (including processing), society (including environment and health) and the consumer level (including credibility of the sector) (Halberg et al., 2012). In these programs funds were allocated to coordination, communication and dissemination, as well as to knowledge synthesis, research methodology and to research education (PhDs at universities and research centres involved in the research) (Halberg et al., 2012). The centre was able to establish and maintain close contact to the players in the sector via user groups and extensive meeting and dissemination activities in order to ensure the continued relevance of research efforts and applicability of results.

In the same period the organic sector has undergone a strong development from its beginning as a niche market and has become an important part of the Danish food sector. The area under organic farming, including the area under conversion in 2010, was $6.4 \%$ of total farmed area (Statistics Denmark, 2012). Of the total food sales in 2010, 7.2 \% was certified organic (Statistics Denmark, 2012) after a dramatic increase in sales from 0.5 billion DKK (approx. $€ 67$ million - or approximately $\$ 80$ million) in 1996 to 5.1 billion DKK (approx. $€ 684$ million - or approximately $\$ 821$ million) in 2010 (Organic Denmark, 2012). Nearly all supermarket chains had a large assortment of organic products and for some product groups, such as eggs and milk, the organic market share was 20-30\% of retail sales (Statistics Denmark, 2012).

It is the view of ICROFS that several important factors have contributed to the positive development of the organic sector in Denmark, including support for marketing and the regulatory framework from public and private sectors; establishment of strong institutions in organic farming; entrepreneurs and pioneers in the organic farming, processing and retailing sectors; as well as research carried out in universities, research stations and together with advisors and farmers at private farms.

\subsection{Impact Assessment}

Impact assessment involves a number of complex issues that are difficult to fully address in a single study (Bloch et al., 2014). Furthermore, conducting cost-benefit analysis and productivity analysis for research is costly (Pedersen et al., 2011). Due to this, it was decided to carry out the analysis as a mixed methods approach, including both quantitative and qualitative methods (Bloch et al., 2014).

The purpose of the analysis of the effect of the organic research was to document the role of research in the development and growth of the organic sector and to achieve a deeper understanding of the utilisation and the effect of the research results in practice. The analysis was published in a report in 2012 (Halberg et al., 2012). The analysis has been conducted by consultants from the Knowledge Centre for Agriculture (now SEGES) (Note 1) and from the Institute of Global Food \& Farming (Note 2) as well as staff from ICROFS.

\section{Methods}

The analysis was based on a triangulation approach (Halberg et al., 2012) to collect qualitative as well as quantitative information from three perspectives (Figure 1), each being independently documented:

1. End-users' (representatives) perception of the R\&D results - to investigate the views of stakeholders on how their part of the sector has developed and the extent to which this has been supported by R\&D

2. Focus and implementation of R\&D research - to investigate the correlation bewteen the resarch projects and the results and effects pointed out by the end-users, as well as comparing research projects with needs identified by the sector and included in the action plans

3. Dissemination of R\&D results - to document which results (and feedback) have been communicated between research and the users of research 


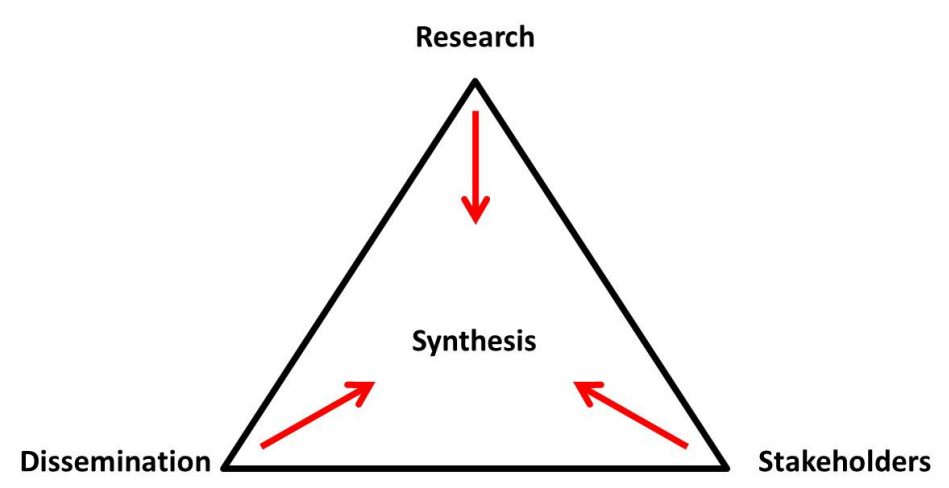

Figure 1. The three perspectives of the triangulation approach used in the organic program evaluation

The purpose of the triangulation method was to create a solid foundation for any conclusions in the areas where R\&D could have had an effect. By combining the three perspectives, it was expected that a robust analysis of the effect of the R\&D effort in the period in question could be made. The triangulation approach was developed based on an analysis framework of the dynamics of research programing and implementation as illustrated in Figure 2. The illustration includes the traditional interpretation of research, dissemination, and use, but not necessarily as separate and consecutive phases. With the flows of information and interactions between phases and with feedback loops to planning and programming the framework becomes more dynamic and illustrative of how the four organic reseach programs have been implemented.

There has been a continuous influence on research by the stakeholders via a number of processes. These include consumer influence on programs where representatives of the sector influence project focus, and also influence from within the projects, as end-users are deliberately involved with scientists in the design of the experiment. This feedback is not systematically included in the current analysis, although the formal influence on the research themes via DARCOF's user group was addressed. While we in this article focus on the effect of research on users, Figure 2 also illustrates direct research products such as scientific papers, conference presentations and $\mathrm{PhD}$ dissertations resulting from these programs.

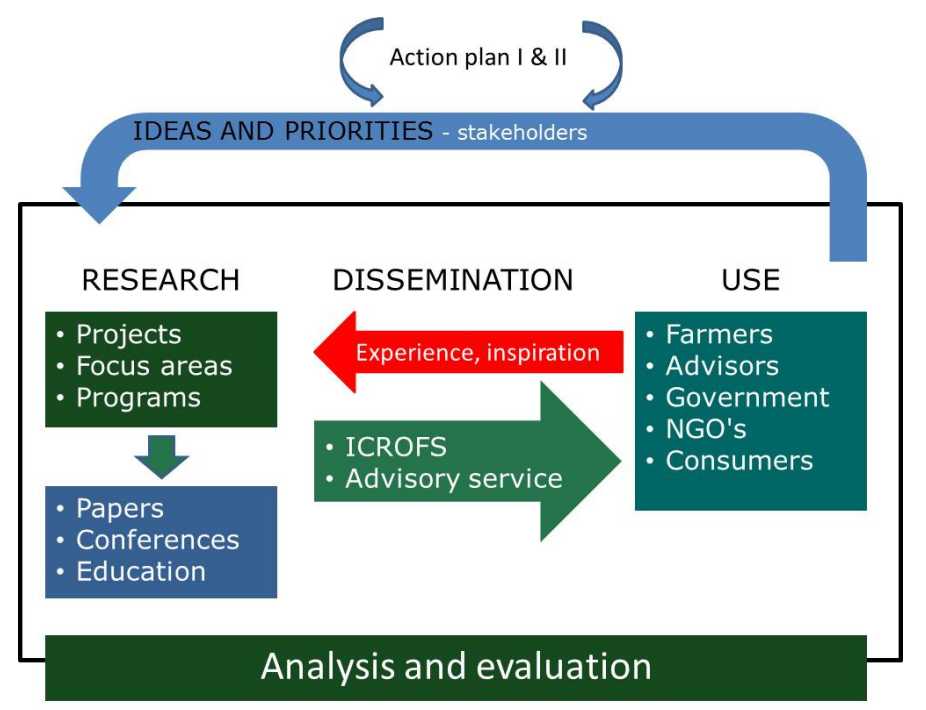

Figure 2. Analysis framework illustrating phases, interactions and communication in the programming and implementation of the four organic research programs 
The findings of the investigations of the three perspectives were compared to identify the areas where R\&D could be documented to have had an effect and the extent of this effect. The R\&D results were judged to have had a positive effect when there was overlap between the end-users' identification of useful results and the dissemination of these results via projects that have focused on these areas - in other words, when there was coincidence between the three perspectives in the triangulation approach (Figure 1). In most cases, these three perspectives were uncovered independently of each other, but in a few cases this has been followed by an in-depth investigation to reveal the link between research and use. This applies to some of the more detailed investigations, where, for example, the results suggested by a scientist as having had a large effect have been verified through targeted interviews with the users.

\subsection{End-users Perception of the R\&D Results - Approach}

This perspective is based on questionnaires and interviews with key persons within the farmer-owned advisory service (in Denmark organised by the farmers' union in local private advisory companies and a central center of expertise as well as the organic movement in Denmark also provides advisory service); with companies in the organic sector; and with a number of other possible end-users in organisations and public authorities.

Primary production advisors: Seven centrally placed advisors within organic crop production, milk, pig, poultry, and fruit/vegetable production, respectively, were interviewed in a systematic process. Fifteen local advisors (dedicated to organic agriculture) in crop production and livestock production were subsequently interviewed using a combination of questionnaires and follow-up interviews. In both types of interviews, the consultants' own understanding of the development in their subsector over the last 10-15 years formed the basis for the discussion. Questions posed included: What were the challenges for the sector, how have they been overcome in practice, how had the production otherwise evolved and to what extent would the consultants attribute this development to the results of R\&D? The advisors are in Denmark important for facilitating the linkage between research and farmers and a main channel for communicating and interpretating results to farmers. To ensure that the respondents would have the information needed to determin to what degree the continuing development and improvement in knowledge could be attributed to $\mathrm{R} \& \mathrm{D}$, the systematic interviews were targeting the advisors as representatives of the end-users. Only in a few cases farmers have been directy involved in the investigations.

Companies: A questionnaire was sent to a total of 15 companies that, partly or exclusively, process and retail organic products. Staff responsible for the organic production was asked to what extent organic R\&D has influenced the development of their company and new products and the supply of commodities. For selected cases the questionnaire was followed up by an in-depth interview.

Organisations and authorities: A number of R\&D projects have focused on topics relevant for society such as the impact of organic farming on environment, animal welfare, etc., and on consumer motivation for purchasing the products. To analyze the effect of these results, a questionnaire was sent to five persons from four public authorities in charge of legislation in the area of organic agriculture and the environment, and to ten persons from seven relevant, private organisations. Key persons were asked to give their views of the most important challenges that the organic sector had been facing in the period of 1996-2010, and to what extent organic research has contributed to solving these issues.

\subsection{Focus and Implementation of $R \& D$ Research - Approach}

The description of this perspective is based on two main sources of information. First, the range of projects was divided into the thematic areas of cattle/milk, pigs, crops, cultivation systems, etc., based on project descriptions and thematic areas in final reports; the scientists' indications of which results they expect to have had an effect and on whom. Thereafter, the focus of the research projects was compared with the relevant recommendations in the two action plans for the development of the organic sector prepared by the Danish Government's Organic Food Council under the auspices of the Ministry of Food, Agriculture and Fisheries in 1995 and 1999 (Det økologiske Fødevareråd, 1995, 1999).

\subsection{Dissemination of $R \& D$ Results - Approach}

To be able to document the extent to which knowledge and results from R\&D projects have been accessible to advisors, an overview of the communications directed at farmers and advisors, scientists and other interested parties was prepared. The Knowledge Centre for Agriculture (VFL) regularly updates advisors with the latest knowledge, and some of this information refers directly to R\&D projects and their investigations and results. By carrying out a search for results of the DARCOF projects and on the themes that were identified under perspective 1 (end-users) as important for the different segments of the sector, it has been possible to determine whether new knowledge in these areas has been conveyed to the local advisors and to the farmers. Due to the 
large number of articles, an exhaustive search has not been made, as sufficient documentation was found for dissemination from projects to end-users in the most important areas.

In relation to all the R\&D programs, DARCOF has taken the initiative to disseminate knowledge from the projects via their own and external media, also facilitating that scientists provided articles to the agricultural press and by supporting web-based communication, the preparation of newsletters, pamphlets and events where the results were presented. Since the start of DARCOF II the projects have been required to report and archive their articles and other written communication in the open-access online archive, Organic Eprints (Note 3). This has made it possible to make a thorough analysis of the output of the projects without having to go through each final report. In this way, publications which have been produced after the end of the project - which is typical for peer-reviewed papers - could also be included in the analysis.

\section{Results}

\subsection{End-users Perception of the R\&D Results - Findings}

Overall the results showed that new research knowledge has had a considerable effect both on the advisory services and on farming practices. The interviewed advisors highlighted, for example, that research results have contributed to higher crop yields (including forage) and improved management of weeds and crop rotations, decreased calf mortality, and higher milk yields and income for dairy cows. Moreover, research and innovations in combined feeding and housing/outdoor keeping significantly improved health, welfare and productivity in pigs and poultry. In Table 1 the main challenges during 1996-2010 in the organic production sector, as identified by the respondents, are listed together with mentioned effects or changed practices at the farm level during the same period of time, the degree to which the challenge was solved, and if research had contributed to the solution.

The private sector respondents provided a couple of good examples of research projects contributing to the development of new products and marketing opportunities, but in general it was found that organic research only to a lesser degree has had an effect on product development. Respondents acknowledged, however, the positive effect of research on the development of the organic market, including growth in volume and turn-over, due to a more stable supply of uniform and high quality raw material. This has, e.g., been a precondition for expanding the processing and marketing of eggs and meat. The government institutions and private organisations responded that research results mainly have had an impact on environmental and animal welfare issues - which had been particularly important in the organic sector from 1996 to 2010. Research had contributed to solving challenges to some or a high degree and had an impact on public awareness and the development of legislation in agriculture, particularly in livestock. 
Table 1. Summary of challenges, solutions, and contributions from research as identified by the advisory services for more details see (Halberg et al., 2012)

\begin{tabular}{|c|c|c|c|}
\hline Challenge & $\begin{array}{l}\text { Success } \\
\text { rating } \\
\text { (Note 4) }\end{array}$ & Effects/change at farm level & $\begin{array}{l}\text { Did } \\
\text { research } \\
\text { (Note 5) } \\
\text { contribute? }\end{array}$ \\
\hline \multicolumn{4}{|l|}{ Crop Production } \\
\hline Crop rotations & 6 & Partial break with conventional thinking & Yes \\
\hline Nutrients & 7 & Optimization of fertilization (crop dependent, nutrient source) & Yes \\
\hline Perennial weeds & 7 & $\begin{array}{l}\text { New strategies for perennial weeds; testing of mechanical } \\
\text { weeding }\end{array}$ & Yes \\
\hline Marketing & 7 & Professionalization and credibility of businesses & No \\
\hline Healthy seed & 6 & - & - \\
\hline \multicolumn{4}{|c|}{ Fruit and vegetables } \\
\hline Yields & 6 & $\begin{array}{l}\text { Intensification of fruit production, planting system, selection } \\
\text { of variety }\end{array}$ & Yes \\
\hline Pests & 5 & $\begin{array}{l}\text { Flower strips (balanced predator-pests populations in } \\
\text { vegetables) }\end{array}$ & Yes \\
\hline Varieties & 5 & $\begin{array}{l}\text { Regular variety testing, development of stable varieties, } \\
\text { quality control }\end{array}$ & Yes \\
\hline Weeds & 6 & $\begin{array}{l}\text { New technologies (mechanical control, flaming, soil cover, } \\
\text { crop rotation) }\end{array}$ & Yes \\
\hline $\begin{array}{l}\text { Market growth/ } \\
\text { sales }\end{array}$ & 7 & $\begin{array}{l}\text { Rationalization, efficiency improvements, specialization, } \\
\text { consumer focus }\end{array}$ & Yes \\
\hline $\begin{array}{l}\text { Product } \\
\text { Development }\end{array}$ & 5 & Consumer focus & - \\
\hline $\begin{array}{l}\text { Org.-conv. } \\
\text { interactions }\end{array}$ & 7 & Open-house events/farm visits, seminars, publications & Yes \\
\hline Credibility & 7 & $\begin{array}{l}\text { Discussion, openness and information, debate, political } \\
\text { responsiveness }\end{array}$ & - \\
\hline \begin{tabular}{ll|} 
Integration & of \\
livestock &
\end{tabular} & - & Organic project demonstration & Yes \\
\hline \multicolumn{4}{|l|}{ Livestock (cattle) } \\
\hline \multirow{2}{*}{$\begin{array}{l}\text { Grazing } \\
\text { (efficiency, land } \\
\text { allocation) }\end{array}$} & \multirow[t]{2}{*}{3} & Regulation & No \\
\hline & & Persistent plant cover close to stables, efficiency in feed value & Yes \\
\hline Calf mortality & 6 & $\begin{array}{l}\text { Reduced by improved housing and management, including } \\
\text { pasteurization of milk for calves }\end{array}$ & Yes \\
\hline Udder health & 4 & $\begin{array}{l}\text { Better economy, animal welfare, milk quality, less use of } \\
\text { antibiotics }\end{array}$ & Yes \\
\hline Forage quality & 5 & $\begin{array}{l}\text { Improved variety selection, plant breeding, admixing of } \\
\text { herbs/less feed supplementation }\end{array}$ & Yes \\
\hline Protein supply & 4 & $\begin{array}{l}\text { Supply stability, protein crop cultivation, testing methods for } \\
\text { feed value, improved sustainability and less climate impact }\end{array}$ & Yes \\
\hline $\begin{array}{l}\text { Consumer } \\
\text { perception }\end{array}$ & 3 & Milk quality (healthy inputs, less antibiotics, taste, diversity) & Yes \\
\hline
\end{tabular}




\begin{tabular}{|c|c|c|c|}
\hline \multicolumn{4}{|l|}{ Livestock (pigs) } \\
\hline Welfare generally & 8 & $\begin{array}{l}\text { Focus on early treatment, culling, control of worms, } \\
\text { behavioral changes }\end{array}$ & Yes \\
\hline $\begin{array}{l}\text { Product (meat) } \\
\text { differentiation }\end{array}$ & 4 & Finishers on grass/Jerusalem artichokes; breeding & Yes \\
\hline Mortality & 4 & More systematic management, vaccination, attention & Yes \\
\hline Environment & 3 & Crop rotation in enclosures, willow and poplar in enclosures & Yes \\
\hline Balanced fodder & 2 & - & Yes \\
\hline Marketing & - & - & No \\
\hline $\begin{array}{l}\text { Stability of feed } \\
\text { supply }\end{array}$ & - & - & No \\
\hline \multicolumn{4}{|l|}{ Poultry } \\
\hline $\begin{array}{l}\text { Diseases } \\
\text { (Erypsipelas, } \\
\text { Pastorella, } \quad \text { E. } \\
\text { Coli) }\end{array}$ & 8 & $\begin{array}{l}\text { Vaccination, reduced infection pressure, better indoor climate, } \\
\text { less stress }\end{array}$ & Yes \\
\hline Predators & 5 & - & $?$ \\
\hline $\begin{array}{l}\text { Behaviour } \\
\text { (e.g. feather } \\
\text { pecking, } \\
\text { cannibalism) }\end{array}$ & 6 & $\begin{array}{l}\text { Optimal nutrition, stimulating environment, stable indoor } \\
\text { climate }\end{array}$ & Yes \\
\hline Economy & 9 & - & $?$ \\
\hline $\begin{array}{l}\text { Ammonia } \\
\text { emission } \\
\text { (housing) }\end{array}$ & 8 & Regular removal of manure, manure stored as slurry & $?$ \\
\hline $\begin{array}{l}\text { Nutrient leaching } \\
\text { (yard) }\end{array}$ & 6 & $\begin{array}{l}\text { Chicken yard as paddock grazing; combinations with } \\
\text { perennial crops }\end{array}$ & Yes \\
\hline
\end{tabular}

\subsection{Focus and Implementation of $R \& D$ Research - Findings}

The projects in the four programs were divided into nine thematic areas for the purpose of this analysis. Livestock production was divided into the different types of livestock (cattle/milk, pigs, poultry/eggs and aquaculture). Crop production was divided into crops and cultivation systems. Finally, thematic areas also include consumption, society and environment, and bioenergy. The government's action plans I and II (Det økologiske Fødevareråd, 1995, 1999) include recommendations for the implementation of research initiatives for solving certain challenges in the sector. Table 2 shows the areas covered by the recommendations and the expected effects of the projects within each of the areas. The DARCOF I projects have primarily had the expected effect on primary production. About 100 scientists from 15 institutions took part in the projects. Moreover, the projects in DARCOF II (200 researchers), DARCOF III (200 researchers) and CORE Organic have had an expected effect on the industry (processing) and on society, including environment and health, and at the consumer level, including integrity. The organic research has thus followed the general growth and development in the sector, embracing new issues along the entire supply chain. 
Table 2. Total number of research projects per thematic area and research program. Many of the research projects addressed more than one research theme, but have been categorized according to main research focus

\begin{tabular}{|c|c|c|c|c|c|c|c|}
\hline \multirow{2}{*}{ Thematic area } & \multicolumn{7}{|c|}{$\begin{array}{l}\text { Research programs, number of projects and relevant action-plan (AP) } \\
\text { recommendations }\end{array}$} \\
\hline & $\begin{array}{l}\text { DARCOF } \\
\text { I }\end{array}$ & $\begin{array}{l}\text { AP I } \\
\text { Rec. }\end{array}$ & $\begin{array}{l}\text { DARCOF } \\
\text { II }\end{array}$ & $\begin{array}{l}\text { AP II } \\
\text { Rec. }\end{array}$ & & $\begin{array}{l}\text { DARCOF III/ } \\
\text { CORE Organic }\end{array}$ & Total \\
\hline Cattle/milk & 1 & & 7 & 2 & & 4 & 12 \\
\hline Pigs & 5 & 1 & 4 & 1 & $*$ & 2 & 11 \\
\hline Poultry/eggs & 1 & 1 & 1 & & $*$ & 0 & 2 \\
\hline Fish & & & & & & 1 & 1 \\
\hline Crops & 7 & 1 & 13 & 7 & $*$ & 5 & 25 \\
\hline Cultivation systems & 14 & $*$ & 10 & 2 & $*$ & 3 & 27 \\
\hline Bioenergy & & & & & & 1 & 1 \\
\hline Consumption & & & 1 & 2 & 2 & 2 & 3 \\
\hline Society and environment & 2 & 2 & 7 & 9 & ) & 4 & 13 \\
\hline Total & 30 & 5 & 43 & 23 & & 22 & 95 \\
\hline
\end{tabular}

* Recommendations apply to several thematic areas.

\subsection{Dissemination of $R \& D$ Results - Findings}

A total of 3,173 publications consituted the direct ourputs from the projects (Organic Eprints, counted in 2012). About $20 \%$ (632) of these were peer-reviewed papers; another 1,311 were other publications in English, while 1,230 were publications or other forms of dissemination in Danish. Based on a search of the archives of Knowledge Centre for Agriculture, it was found that there had been dissemination based on R\&D in the projects within all the thematic areas. One example is the Danish Crop Rotation Experiment, from which there were 215 publications in Organic Eprints, and at least 50 dissemination articles based on the R\&D in the archives of Knowledge Centre for Agriculture. In the interviews, there were many statements about contributions from research [see, for example Chapter 4 in Halberg et al. (2012)]. In each case, it was determined that there was research results disseminated, so that the statements were justified.

\section{Discussion}

The projects resulted in a high number of peer reviewed journal articles, in spite the fact that the research under the four programs has mainly been 'applied research'. As this paper is focused on the effects of the research programs we will, however, mainly discuss how the close association between scientists and end-users in the DARCOF programs has had a large bearing on the effects achieved. The below discussion is based on the results provided in section 3. For certain details reference may be given to the analysis report by Halberg et al. (2012).

A certain degree of uncertainty is attached to the qualitative information of the analysis as it builds on personal observation as well as the fact that respondents may have had different interests in the research. The triangulation approach has been used to remedy this uncertainty thereby verifying that research related to the specific challenge has taken place and that research-based solutions have been disseminated. It should, however, also be noted that this analysis is expected to be conservative in its results, as the user survey was based on a limited number of interviews and the persons interviewed may not have been aware of the practical implications of specific results from R\&D, although these results have, in reality, been of benefit for other users.

\subsection{Direct Effects on Sector, Growth and Production Forms}

There has been a large and significant effect of the research under the four programs on the development of the organic sector. Both crop production and animal husbandry research projects have contributed with significant new knowledge and methods in response to the considerable challenges in primary production, from the handling of manure and weeds to animal health and feeding. The results have been widely applied, partly because many of the projects have been designed and selected as a response to challenges formulated by the sector. The advisors believe that organic production would have been much lower today if the research results had not been utilized. This is because the production itself is more profitable (higher yields per cow, pigs of 
higher quality resulting in a higher kilo price, etc.) and because some important problems have been solved, which has reduced the incidence of reconversion to conventional farming (for example, improved perennial weed control and recycling of nutrients with the use of cover crops and good crop rotations).

The increasing production and the ability to ensure a good and consistent quality and stability has also been a precondition for the establishment of a professional and profitable processing sector. The companies interviewed found that these conditions have had an important effect on their development opportunities.

Overall, this shows that the research in the DARCOF programmes and CORE Organic had a strong focus on the barriers in the sector and on improving the general market and growth conditions in the sector. Accordingly, the research has laid the basis for a stronger commercial exploitation of the opportunities and the research focus has been consistent with the challenges in the commercial sector and also the political ambitions for market-driven growth in the organic sector.

\subsection{Indirect Effects, Greater Integrity and Policy Developments}

In addition to the direct effects, there are other - more indirect - effects on processing and marketing, such as a better understanding of consumer motives for purchasing organic produce and a higher degree of integrity as a result of research. Integrity - here understood as consumer trust that the organic sector lives up to its declared ideals and added values - has been improved in two ways. First, the organic production itself has been improved in areas that are important to the consumer, and second, studies have evaluated organic farming in relation to its principles, consumer expectations and/or interests of society. In the first instance, research projects have according to interviews with consultants and representatives of public authorities and organizations - enhanced animal health and welfare on organic farms through the development and description of better farm management, housing, feeding, etc. In the second instance, a series of projects have probed whether organic farming actually confers advantages compared with conventional systems or products.

In this connection, the projects are both actual research projects and a large number of scientific reviews - the so-called knowledge syntheses - prepared under DARCOF programs and prepared with participation of scientists from the DARCOF projects. Some of these projects have documented positive effects of organic farming on, for example, nutrient balances in livestock farming, conservation of biodiversity in hedgerows, as well as a higher nutritional content of organic produce. However, some results have also been critical regarding specific aspects of organic farming, e.g., when measured either on climate impact per kilo of produce, on flavor or on general healthiness.

In several instances, such results have been used by organizations in the sector to launch campaigns to improve practical aspects of the systems (Note 6). In other instances the sector has focused on improving animal health and welfare on organic farms based on the background of research projects and reviews. It can be assumed that the willingness to admit to weaknesses in the organic systems and the readiness to seek solutions to these has helped maintain integrity in the eyes of the public and ensured the continued political backing, although there is no documentation for this. The assumption is, however, supported by interviews with representatives from organiszations and government (Halberg et al. 2012).

\subsection{Consumers and Markets and Effects on Conventional Farming}

Some of the research projects have documented that large consumer segments favor organic produce for a variety of personal (health, quality, pesticide-free) and altruistic (animal welfare, environment) reasons. These preferences may also affect conventional food production. In addition to the described effects on the organic sector the DARCOF projects have also produced results that are relevant for conventional farming and can aid a general green conversion. This is true, for example, for methods to replace seed treatments, non-chemical weed control, and a reduction in the consumption of antibiotics and the need for supplementation of synthetic vitamins in animal husbandry. This could give large cash savings in the conventional sector if the methods were widely implemented and would further improve the reputation of Danish agriculture as an eco-friendly system supplying high-quality products.

\section{Conclusions}

At the international level there is an awareness of the need to improve the relationship between research, extension and agricultural production. In the "International Assessment of Agricultural Knowledge, Science and Technology for Development (IAASTD" (McIntyre et al., 2009), the conclusions stress the fact that it is necessary for a strict departure from the traditional model of research and dissemination as separate actions. Instead, there is a need for the farmers' situation to have a stronger voice when prioritizing and designing research projects and to integrate their local knowledge and experience into research schemes (Aagaard-Hansen 
et al., 2007).

The very applied nature and relevance of the projects under the DARCOF programs has been strengthened via the close and continuous contact with consumer representatives, first and foremost, in formal fora such as the user group in DARCOF. There has also been contact with the sector via the organic food council and a number of other actors involved in the preparation of the action plans and later in the knowledge synthesis in 2008 (Alrøe et al., 2008) on the potential for a market-based development of the organic sector. This influence at program level has been - and continues to be - important for maintaining the relevance of the projects offered and funds granted in relation to the requirements of the sector.

At the same time, many of the projects have had contact with advisors and farmers where the acquired knowledge has been continually communicated and discussed. This has had two effects. Firstly, a rapid application of results, because the users have discussed the results of the research with the scientists and thus achieved a better understanding of how results and knowledge can be adapted to specific practical situations; and secondly, there has in many projects been an adaptation of research design and methodology as a result of practical experience. The scientists have been persuaded by the dialogue with the users to ensure that treatments are as relevant and practical as possible, without compromising scientific standards.

This shows that there is a more complex connection between research, development and the application of knowledge in agriculture than the traditional route of one-way communication of scientific results via advisors to producers. Because the project structure and organization of the organic research programs have supported this complexity in knowledge generation and exchange, clear indications suggest that there has been a good effect of the research projects measured in terms of the utilisation of the results and overcoming main barriers in the sector. An additional but important factor is that regardless of the 3-5-year duration of the research programmes, there has been continuity in many central research activities in terms of long-term experiments at the same localities over many years and in many research programmes.

\section{References}

Aagaard-Hansen, J., Larsen, C. E. S., Halberg, N., Hjortsø, C. N., Gausset, Q., \& Kabirizi, J. (2007). Main-streaming participatory and cross-disciplinary approaches in animal science research in developing countries. African Journal of Agricultural Research, 2 (4), 119-130.

Alrøe, H. F., \& Halberg, N. (Eds.) (2008). Udvikling, vækst og integritet i den danske økologisektor. Vidensyntese om muligheder og barrierer for fortsat udvikling og markedsbaseret vækst i produktion, forarbejdning og omsætning af økologiske produkter. [Development, growth and integrity in the Danish organic sector. A knowledge synthesis on the opportunities and barriers for a continued development and market-based growth in production, processing, and sale of organic products.] ICROFS-rapport, no. 1. Internationalt Center for Forskning i Økologisk Jordbrug og Fødevaresystemer (ICROFS), Denmark.(http://orgprints.org/15396/, Summary in English can be found here: http://www.icrof.org/Pages/Publications/synthesis_08.pdf)

Bloch, C., Sørensen, M. P., Graversen, E. K., Schneider, J. W., Schmidt, E. K., Aagaard, K., \& Mejlgaard, N. (2014). Developing a methodology to assess the impact of research grant funding: A mixed methods $\begin{array}{lllll}\text { approach. Evaluation and Program } & \text { Planning, 43, }\end{array}$ http://dx.doi.org/10.1016/j.evalprogplan.2013.12.005

Det økologiske Fødevareråd. (1995). Aktionsplan for fremme af den økologiske fødevareproduktion i Danmark (p. 418). Landbrugs- og Fiskeriministeriet, Strukturdirektoratet. Kbh.

Det økologiske Fødevareråd. (1999). Aktionsplan II Økologi i udvikling (p. 368). Ministeriet for Fødevarer, Landbrug og Fiskeri, Strukturdirektoratet. Kbh.

Halberg, N., Kledal, P. R., Rasmussen, I. A., Mathiesen, C., Sørensen, L. S., Jespersen, L. M., \& Madsen, K. H. (2012). Organic research and development 1996-2010 - effects on industry and society. International Centre for Research in Organic Food Systems (ICROFS), Tjele, Denmark.

McIntyre, B., Herren, H. R., Wakhungu, J., \& Watson, R. T. (2009). 'Agriculture at a Crossroads', Synthesis Report and Global Summary for Decision makers, IAASTD, Retrieved December 4th, 2011, from www.agassessment.org/reports/IAASTD/EN/Agriculture\%20at\%20a\%20Crossroads_Synthesis\%20Report $\% 20$ (English).pdf

Organic Denmark. (2012). Økologisk Markedsnotat, Juni 2012. Økologisk Landsforening. Retrieved from http://www.okologi.dk/virksomhed/hjemmemarked/markedsinformation.aspx 
Pedersen, S. M., Boesen, M. V., Baker, D., Larsen, A., \& Pedersen, J. L. (2011). Evaluation of research projects perspectives for applied research in food and agriculture. Food Economics - Acta Agriculturae Scandinavica C, 8, 127-141. http://dx.doi.org/10.1080/16507541.2011.644438

Statistics Denmark, Statistikbanken, Landbrug og Fiskeri: Retrieved August 12, 2012, from http://www.statistikbanken.dk/statbank5a/default.asp?w=1024

\section{Notes:}

Note 1. http://www.seges.dk/English/NyEnglishsite.htm

Note 2. http://www.igff.dk/

Note 3. Organic Eprints: http://orgprints.org/

Note 4. Success rating: $1=$ no progress since 1996, $10=$ the challenge has been solved

Note 5. Research in this context refers to the DARCOF I, II and III programs and CORE Organic

Note 6. http://www.dyrenesbeskyttelse.dk/kalved\%C3\%B8delighed\#hw1mQEi1GAplvfFy.97;

https:/www.okologi.dk/media/474384/kalveskoler\%20er\%20en\%20succes\%20440-okt\%2009.pdf

\section{Copyrights}

Copyright for this article is retained by the author(s), with first publication rights granted to the journal.

This is an open-access article distributed under the terms and conditions of the Creative Commons Attribution license (http://creativecommons.org/licenses/by/3.0/). 